\title{
The International Academy of Health Sciences Informatics (IAHSI): 2020 Report
}

\author{
Reinhold Haux', Marion J. Ball ${ }^{2}$, William R. Hersh ${ }^{3}$, Elaine Huesing ${ }^{4}$, Michio Kimura $^{5}$, \\ Sabine Koch ${ }^{6}$, Fernando Martin-Sanchez ${ }^{7}$, Paula Otero ${ }^{8}$ \\ 1 Peter L. Reichertz Institute for Medical Informatics of TU Braunschweig and Hannover Medical \\ School, Braunschweig, Germany \\ 2 Multi-Interprofessional Center for Health Informatics, University of Texas at Arlington, Arlington, \\ TX, USA \\ 3 Department of Medical Informatics \& Clinical Epidemiology, Oregon Health \& Science University, \\ Portland, OR, USA \\ 4 International Medical Informatics Association (IMIA) \\ 5 Medical Informatics Department, School of Medicine, Hamamatsu University, Shizuoka, Japan \\ 6 Health Informatics Centre, Department of Learning, Informatics, Management and Ethics, \\ Karolinska Institutet, Stockholm, Sweden \\ 7 Digital Health Research Department, Instituto de Salud Carlos III, Madrid, Spain \\ 8 Department of Health Informatics, Hospital Italiano de Buenos Aires, Buenos Aires, Argentina
}

\begin{abstract}
Summary
Objectives: To summarize the major activities of the International Academy of Health Sciences Informatics (IAHSI) in the 2020 time period and to welcome its 2020 Class of Fellows. Method: Report from the members of the Academy's Board. Results: Due to the SARS-CoV-2 pandemic, both Plenary meetings in 2020 had to be organized as virtual meetings. Scientific discussions, focusing on mobilizing computable biomedical knowledge and on data standards and interoperability formed major parts of these meetings. A statement on the use of informatics in pandemic situations was elaborated and sent to the World Health Organization. A panel on data standards and interoperability started its work. 34 Fellows were welcomed in the 2020 Class of Fellows so that the Academy now consists of 179 members.

Conclusions: There was a shiff from supporting to strategic activities in the Academy's work. After having achieved organizational stability, the Academy can now focus on its strategic work and so on its main objective.
\end{abstract}

\section{Keywords}

Biomedical and health informatics; Medical informatics; Health informatics; Academy of Sciences; International Academy of Health Sciences Informatics; International Medical Informatics Association

Yearb Med Inform 2021:8-12 http://dx.doi.org/10.1055/s-0041-1726479

\section{Introduction}

Established in 2017, the International Academy of Health Sciences Informatics (IAHSI) [1], through the auspice and as a component of IMIA, the International Medical Informatics Association [2]:

- aims to contribute to the health and well-being of the people in our world through health sciences informatics;

- promotes the dissemination of knowledge and best practices, fosters new ideas, and encourages worldwide collaboration and sharing of expertise and resources; and

- seeks to nominate and elect those whose contributions in biomedical and health informatics are recognized internationally $[1,3-5]$.

After the Academy "is now established and on track" [4] we, the Academy's current Board with its elected and ex-offico members, will from now on present yearly reports, focusing on the Academy's work during these annual periods. And we will continue to welcome the newly elected Fellows.

This 2020 report:

- presents content and time pattern of IAHSI's Plenary meetings (section 2),

- outlines the Academy's strategic activities (section 3),
- welcomes the members of the 2020 Class of Fellows (section 4),

- shows some data on the Academy's membership (section 5),

- informs about elections to the Academy Board (section 6), and

- lists further organizational activities (section 7)

in the period from September 2019 to November $2020^{1}$.

\section{Plenary Meetings}

After five Academy Plenary meetings have taken place, we can observe a certain 'convergence' in the contents and in the time pattern of these meetings.

On the time pattern: Within each year ...

- ... there is one major Plenary meeting, usually in / around August. This meeting is a one-day face-to-face meeting plus virtual participation. As specified in the

\footnotetext{
The 2020 report covers the period from after the $3^{\text {rd }}$ Academy Plenary meeting, held as a one-day face-to-face meeting plus virtual participation on August $25^{\text {th }}, 2019$, in Lyon, France, until and including the $5^{\text {th }}$ Academy Plenary meeting, held in November 2020.
} 
Academy's Bylaws [6], it takes place at the location of the annual IMIA General Assembly meeting and close to the date of this meeting, usually in association with a major international medical informatics conference such as MedInfo.

- ... there is one intermediate Plenary meeting, usually in / around April. This meeting is a two- to three-hour virtual meeting, maybe plus face-to-face participation. A face-to-face meeting location may be at the place where an IMIA Board meeting is scheduled, probably along a major international medical informatics conference.

On the contents:

- At each of the Plenary meetings and as usual in Academies, scientific discussions are in the primary focus of these meetings. After the participating Fellows have introduced themselves and after some introductory remarks, this is the first topic, covering most of the meeting time.

- In the last part organizational matters are discussed.

- At the major Plenary meetings, around noon, in addition a welcome ceremony for new Fellows takes place, with handing over of certificates.

During this time period the $4^{\text {th }}$ (intermediate) Plenary meeting took place on April $27^{\text {th }}, 2020$. Because of the SARS-CoV-2pandemic, we had to cancel the face-to-face part of the meeting, which was planned to take place in Geneva, Switzerland, in association with an IMIA Board meeting and with the MIE 2020 conference. The $5^{\text {th }}$ (major) Plenary meeting, originally planned as a primarily face-to-face meeting in Hamamatsu, Japan, also had to be organized as a primarily virtual meeting. With this change it was shortened from a one day to a twohour meeting, taking place on November $21^{\text {st }}$ local time in Japan (November $20^{\text {th }}$ in UTC) right before the opening of the APAMI 2020 conference.

Scientific topics discussed during the $3^{\text {rd }}, 4^{\text {th }}$, and $5^{\text {th }}$ Plenary meetings were on artificial intelligence in health, on the current landscape of standards in digital health (both at the $3^{\text {rd }}$ Plenary), on mobilizing computable biomedical knowledge (4 ${ }^{\text {th }}$ Plenary), and on data standards and interoperability $\left(5^{\text {th }}\right.$ Plenary). In the $1^{\text {st }}$ and $2^{\text {nd }}$ Plenary meetings, where the Academy's founding process was still the major focus, the visions for IAHSI [5] and its strategy and focus areas [7] were subjects of scientific debates.

\section{Strategic Activities}

Figure 1, taken from [4] and [7], helps to understand the current status of IAHSI's strategic activities.

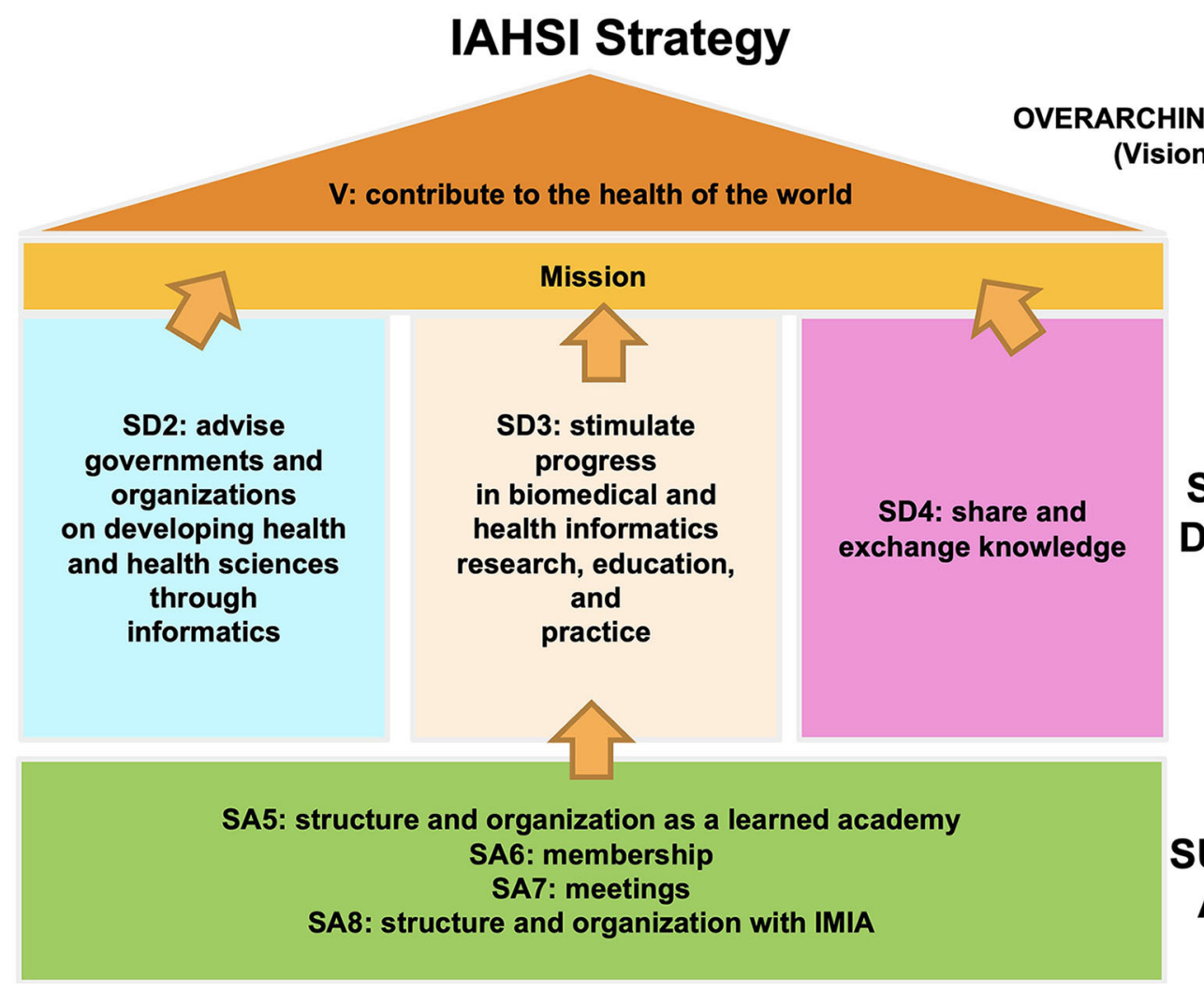

Fig. 1 Goal, directions, and activities of the Academy's strategy (taken from $[4,7]$ ). 
During the time period, covered by this report, a certain focus still had to be laid on setting up processes for the Academy's "supporting activities" SA5 to SA8.

Activities for the Academy's "strategic directions" SD2 to SD4 could however be intensified:

- Through its scientific debates, described in the previous section, the work on the Academy's strategic directions was started.

- In March 2020 a statement on the use of informatics in pandemic situations had been elaborated and sent to the Director General of the World Health Organization [8].

- In October 2020 a panel on data standards and interoperability was initiated.

In the coming years, the Academy will be able to focus stronger on its strategic directions, whereas work on supporting activities will decrease, as processes are now much better established.

\section{Electing the 2020 Class of Fellows}

Academy Membership is one of the highest honors in the international field of biomedical and health informatics. Academy Fellow candidates must have the following qualifications $([6,9])$ :

- Accomplishment: The candidate should generally have a high level of training and experience, recognized research, implementation or policy achievement and contribution, educational impact, or other significant leadership in biomedical and health informatics over a minimum of ten years, and often for much longer.

- Recognition: In those countries or regions where this is possible, it is pertinent if the candidate is an elected member of an academy of sciences or an equivalent organization.

- Global Engagement:The candidate should be engaged internationally. International involvement can be demonstrated through international activities, in particular in research, publication, education, or through international leadership roles in IMIA or in one of the regional international medical informatics organizations of IMIA.
In addition regional and gender balance is highly considered.

In a diligent nomination and election procedure that carefully considered these eligibility criteria, the Academy's 2020 Class of Fellows was elected [10]. Please join us in congratulating the 34 Fellows of the 2020 Class of the International Academy of Health Sciences Informatics (Table 1). These new
Fellows have achieved worldwide recognition and admiration by their peers and are truly the leaders and mentors of our field!

All current Academy Fellows can nominate new candidates for Fellowship. Deadline for classes in future years is March $1^{\text {st }}$ of the respective year. Further details on the nomination process can be found in [9], and on the Academy's election rules in [6].

Table 1 Fellows of the 2020 Class of the International Academy of Health Sciences Informatics.

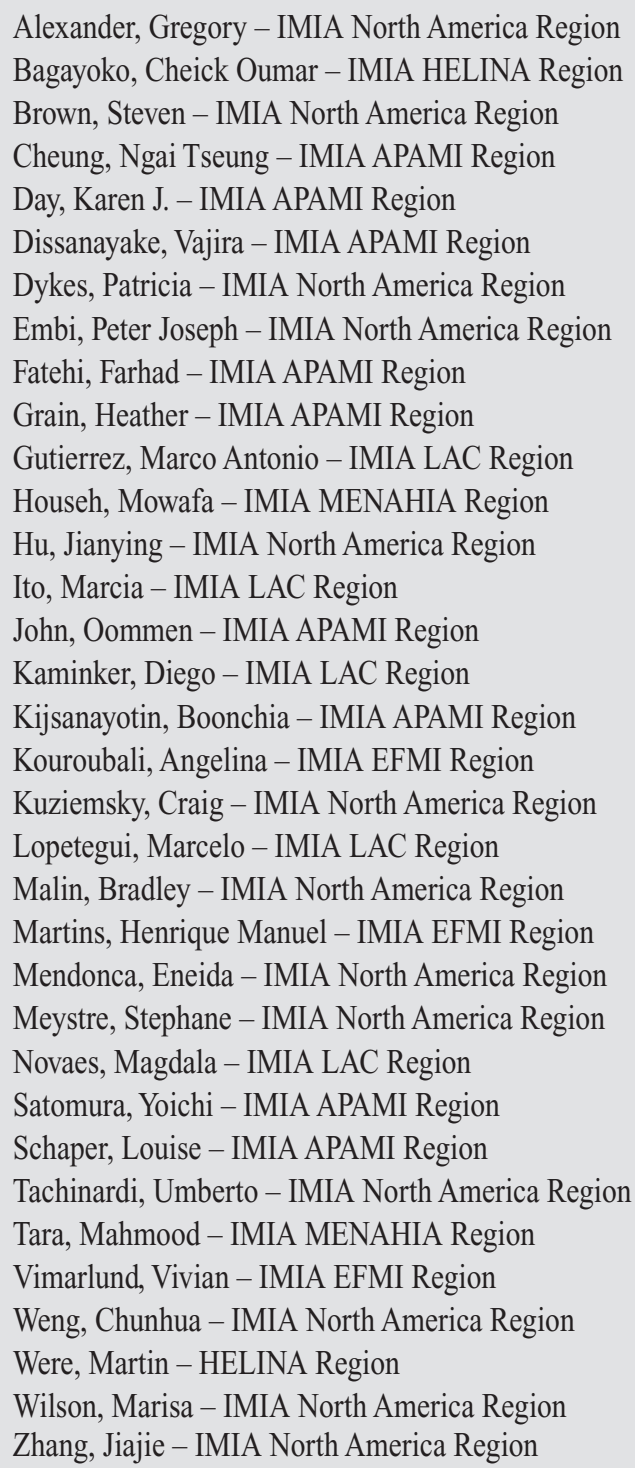




\section{Membership}

The number of Fellows and their regional and gender distribution by class is presented in Table 2. Organizations representing regions within IMIA are HELINA for Africa, APAMI for Asia-Pacific, EFMI for Europe, IMIA-LAC for Latin America, MENAHIA for the Middle East, while North America is jointly represented by AMIA and $\mathrm{COACH}$ (details in [1]).

\section{Elections to the Board}

In March 2020, William (Bill) Hersh was elected incoming President. His two-year term as President of the Academy started immediately after the $5^{\text {th }}$ Plenary meeting in November 2020. After election, Bill participated in the Academy's Board meetings similar to future Presidents-Elect ${ }^{2}$.

In October 2020, Don Detmer was elected Board Member at Large. His two-year term started immediately after the $5^{\text {th }}$ Plenary meeting in November.

Board members during the time period of this 2020 report were Marion Ball (Member at Large), Reinhold Haux (President), Bill Hersh (incoming President), Elaine Huesing (ex officio as CEO of IMIA), Michio Kimura (Treasurer), Sabine Koch (ex officio as President of IMIA), Fernando Martin-Sanchez, (Member at Large, until January 2020), Paula Otero (Secretary).

\section{Further Organizational Activities}

Further organizational work has been done, among others, on the Academy's finances, on its web pages, and on specifying the Board members' terms of office. The process of electing new Fellows has been refined and ambiguities in interpreting the Academy bylaws were discussed and clarified. The Academy's various publications and an-

2 During the Academy's starting phase the first two Presidents did not have a President-Elect period before becoming President.

Table 2 Fellows of the International Academy of Health Sciences Informatics as of August 17th, 2020.

\begin{tabular}{|c|c|c|c|c|c|c|}
\hline & Africa & $\begin{array}{l}\text { Asia- } \\
\text { Pacific }\end{array}$ & Europe & $\begin{array}{c}\text { Latin } \\
\text { America }\end{array}$ & $\begin{array}{c}\text { Middle } \\
\text { East }\end{array}$ & $\begin{array}{c}\text { North } \\
\text { America }\end{array}$ \\
\hline \multirow{2}{*}{$\begin{array}{c}\text { Inaugural } \\
\text { Class } \\
2017 \\
\end{array}$} & $\begin{array}{c}4 \\
3 \%\end{array}$ & $\begin{array}{c}20 \\
17 \%\end{array}$ & $\begin{array}{c}42 \\
35 \%\end{array}$ & $\begin{array}{c}10 \\
8 \%\end{array}$ & $\begin{array}{c}5 \\
4 \%\end{array}$ & $\begin{array}{c}38 \\
32 \%\end{array}$ \\
\hline & \multicolumn{6}{|c|}{ female $30(25 \%)$, male: 89 (75\%), all: 119} \\
\hline \multirow{2}{*}{$\begin{array}{c}2018 / 2019 \\
\text { Class }\end{array}$} & $\begin{array}{c}1 \\
5 \%\end{array}$ & $\begin{array}{c}4 \\
15 \%\end{array}$ & $\begin{array}{c}10 \\
38 \%\end{array}$ & $\begin{array}{c}0 \\
0 \%\end{array}$ & $\begin{array}{c}0 \\
0 \%\end{array}$ & $\begin{array}{c}11 \\
42 \%\end{array}$ \\
\hline & \multicolumn{6}{|c|}{ female: $10(38 \%)$, male: $16(62 \%)$, all: 26} \\
\hline \multirow{2}{*}{$\begin{array}{l}2020 \\
\text { Class }\end{array}$} & $\begin{array}{c}2 \\
6 \%\end{array}$ & $\begin{array}{c}9 \\
26 \%\end{array}$ & $\begin{array}{c}3 \\
9 \%\end{array}$ & $\begin{array}{c}5 \\
15 \%\end{array}$ & $\begin{array}{c}2 \\
6 \%\end{array}$ & $\begin{array}{c}13 \\
38 \%\end{array}$ \\
\hline & \multicolumn{6}{|c|}{ female: $12(35 \%)$, male: $22(65 \%)$, all: 34} \\
\hline \multirow[t]{2}{*}{ all Fellows } & $\begin{array}{c}7 \\
4 \%\end{array}$ & $\begin{array}{c}33 \\
18 \%\end{array}$ & $\begin{array}{c}55 \\
31 \%\end{array}$ & $\begin{array}{l}15 \\
8 \%\end{array}$ & $\begin{array}{c}7 \\
4 \%\end{array}$ & $\begin{array}{c}62 \\
35 \%\end{array}$ \\
\hline & \multicolumn{6}{|c|}{ female: 52 (29\%), male: 127 (71\%), all: 179} \\
\hline
\end{tabular}

nouncements during the time period of this 2020 report can be found at and accessed through IAHSI's announcements and publications web page.

In order to prepare the Plenaries, to organize the elections, and to assist in or carry out the mentioned activities during this time period, Board meetings took place on October $21^{\text {st }}$ and November $20^{\text {th }}$ in 2019 as well as on January $15^{\text {th }}$, February $11^{\text {th }}$, March $18^{\text {th }}$, June, $4^{\text {th }}$, July $8^{\text {th }}$, and September $16^{\text {th }}$ in 2020 . All meetings took place virtual, usually for two hours and usually starting at 2 PM UTC.

\section{Acknowledgements}

We cordially want to thank all colleagues, who contributed to the work of the Academy. Special thanks go to the speakers of the scientific debates (in this time period Chuck Friedman, Ed Hammond, and Jeremy Wyatt), to the members of the health informatics in pandemics committee (chaired by Najeeb Al-Shorbaji), and to the initiators of IAHSI's panel on data standards and interoperability (Ed Hammond together with Beatriz de Faria Leao and Diego Kaminker). We are aware that many others should be mentioned here, too. Thank you all so much!

\section{A Final Personal Note ...}

... from the outgoing President: It was an exceptional honor for me having been elected as the Academy's first President and to serve the Academy in this role during the last years. My sincere thanks go to the many colleagues, who were engaged in the Academy's activities, to all Board members (a dream team!) and to those who had the long, long breath to getting IAHSI established. During the last years the world seemed to become more and more filled up with national egoisms and hate. For some people, even for some leaders, 'fake news ${ }^{63}$ seem to have become an accepted way to push interests. Especially during such times it becomes aware how important it is to have institutions like IAHSI, where its member have the clear and strong will to "collaborate in a tolerant, collaborative, and peaceful manner, transcending nations, cultures, religions, gender, and political or social structures" aiming "to contribute to the health and well-being of the people in our world" [6]. I am so glad and proud that there is IMIA and that IAHSI is a part of it.

\section{References}

1. International Academy of Health Sciences Informatics (IAHSI) [cited 2020 Oct 28]. Available from: https://imia-medinfo.org/wp/iahsi/

2. International Medical Informatics Association (IMIA) [cited 2020 Oct 28]. Available from: https://imia-medinfo.org

3. Lehmann CU, Park HA, Shortliffe EH, Degoulet P. The International Academy of Health Sciences Informatics: An Academy of Excellence. Yearb Med Inform 2017;26:7-8.

4. Haux R, Ball MJ, Kimura M, Martin-Sanchez F, Otero P, Huesing E, Koch S, Lehmann CU. The International Academy of Health Sciences

In my opinion an unacceptably trivializing term for nothing else but lies. 
Informatics (IAHSI): IMIA's Academy is Now Established and on Track. Yearb Med Inform 2020;29:11-4.

5. Haux R. Visions for IAHSI, the International Academy of Health Sciences Informatics. Yearb Med Inform 2018;27:7-9.

6. Bylaws of the International Academy of Health Sciences Informatics (IAHSI). Approved by the Academy Plenary on August 25, 2019, and by the IMIA General Assembly on August 26, 2019 [cited 2020 Oct 28]. Available from: https://imia-medinfo.org/wp/wp-content/uploads/2018/08/IAHSI-Bylaws-approved-August-2019.pdf

7. Martin-Sanchez F, Ball MJ, Kimura M, Otero P, Huesing E, Lehmann CU, Haux R. International Academy of Health Sciences Informatics (IAHSI):
Strategy and Focus Areas, 1st Version. Yearb Med Inform 2020;29:15-25.

8. Statement from the International Academy for Health Sciences Informatics (IAHSI), the Academy of the International Medical Informatics Association (IMIA), to the Director General of the WHO on the Use of Informatics in Pandemic Situations. March 25, 2020 [cited 2020 Oct 28]. Available from: https:// imia-medinfo.org/wp/statement-from-the-international-academy-for-health-sciences-informatics-iahsi-the-academy-of-the-international-medical-informatics-association-imia-to-the-directorgeneral-of-the-who-on-the-use/

9. IAHSI Nomination Process for New Fellows [cited 2020 Oct 28]. Available from: https://imia-medinfo. org/wp/iahsi-nomination-process-for-new-fellows/ 10. IAHSI Announces the 2020 Class of Fellows. IMIA announcement on August 17,2020 [cited 2020 Oct 28]. Available from: https://imia-medinfo.org/wp/ iahsi-announces-the-2020-class-of-fellows/

\section{Correspondence to:}

Prof. Dr. Reinhold Haux

President of IAHSI (2018-2020)

Peter L. Reichertz Institute for Medical Informatics

of TU Braunschweig and Hannover Medical School Muehlenpfordtstr. 23

D-38106 Braunschweig

Germany

E-mail:Reinhold.Haux@plri.de

www.plri.de 